\title{
Seniman sebagai Pemilik Galeri Studi Komparasi antara Tiga Manajemen Galeri Swasta di Yogyakarta
}

\author{
Heri Wijayanto \\ Program Pascasarjana Institut Seni Indonesia Yogyakarta \\ hrwjnt@gmail.com
}

\begin{abstract}
Abstrak
Penelitian ini bertujuan untuk mengetahui perbedaan manajemen galeri swasta di Yogyakarta dan peran pemilik galeri yang berprofesi sebagai seniman, masing-masing galeri memiliki ciri khas yang membedakan dengan galeri lainnya. Manfaat penelitan ini menjelaskan tentang manajemen dalam galeri swasta, antara lain: "Museum Dan Tanah Liat", "Kersan Art Studio" dan "Sangkring Art Space". Seniman yang ingin berpameran setidaknya mengerti akan pentingnya jaringan pertemanan dan lebih memahami akan karakter galeri yang menjadi tujuan pameran. Metode yang digunakan dalam penelitian ini menggunakan metode kualitatif deskriptif dengan menggunakan data primer sebagaimana peneliti lakukan melalui wawancara kepada pemilik galeri dan manajemen galeri, sedangkan data sekunder digunakan untuk mendukung penelitian dengan mengumpulkan dokumen seperti katalog, poster dan media promosi yang digunakan dalam internet. Membandingkan hasil peneltian yang didapat dengan mencari perbedaan pada peran pemilik dan manajemen dalam galeri. Hasil penelitian ini menunjukkan bahwa setiap pemilik galeri memiliki peran masing-masing terhadap manajemen. Kurator dalam sebuah manajemen memiliki peran yang sangat penting untuk menafsirkan karya seni rupa dan mematangkan sebuah konsep kegiatan pameran. Jaringan pertemanan menjadi paling penting dalam sebuah galeri, karena setiap galeri yang memamerkan karya seni tidak jauh dari pertemanan tersebut. Direktur atau General Manager sebagai pengendali utama dalam manajemen, galeri rata-rata tidak memiliki latar belakang pendidikan manajemen, meski demikian, manajemen galeri menerapkan teori fungsi manajemen mengenai; 1) Perencanaan dan penyusunan strategi, 2) Pengorganisasian, 3) Pengendalian, 4) Memimpin dan mengembangkan karyawan.
\end{abstract}

Kata kunci: seniman sebagai pemilik galeri, manajemen galeri swasta, fungsi manajemen

\begin{abstract}
This study aims to determine the differences between private gallery management in Yogyakarta and the role of gallery owners who work as artists. Each gallery has distinctive characteristics that differentiate it from others. The benefit of this research explains about the management of private galleries: "Museum dan Tanah Liat", "Kersan Art Studio" and "Sangkring Art Space". Artists who want to exhibit their artworks should at least understand the importance of friendship networking and better understand the character of the gallery in which the exhibition is held. The method used in this study is descriptive qualitative in which primary data was obtained by interviewing gallery owners and gallery management, while secondary data was used to support research by collecting documents such as catalogs, posters and promotional media in the internet. Then, the data was processed by coding the indicator that became the result of the interview and analysis. The result of the analysis is to compare the three galleries with the differences in each of the galleries. There is a difference in the role of gallery owners to the management, program activities and criteria of the
\end{abstract}


artworks exhibited in each gallery. The results of this study indicate that each gallery owner has their own respective roles toward management. The curator in a management has a very important role to interpret the artworks and finalize a concept of exhibition activity. Friendships are the most important in a gallery because every gallery exhibit artworks which are not far from that friendship. Evenly, directors or general managers as the main controller in management does not have management education background, however, the gallery management implements the management function theory regarding; 1) strategic planning and preparation, 2) organizing, 3) controlling, 4) leading and developing employees.

Keywords: artists as gallery owners, management of private galleries, function of management

\section{Pendahuluan}

Galeri merupakan suatu ruangan yang digunakan untuk menampilkan karya-karya seni, Cyril (2006: 451). Sedangkan menurut Mike (2011: 45), galeri merupakan tempat seniman pameran atau jualan karya seni rupa, artinya, galeri bisa bertujuan ideal (bersifat nonkomersial/untuk apresisi) maupun yang komersial dengan tujaun menjual karya. Dari kedua pengertian tersebut dapat diambil kesimpulan bahwa galeri merupakan suatu gedung, terdapat ruangan khusus untuk menampilkan karya seni para seniman yang bertujuan untuk diapresiasi ataupun dengan tujuan komersial.

Menurut Yi-Fu Tuan dalam Arya Sucitra (2015), kategori ruang (artspace) mendefinisikan kategori ruang pragmatis sekaligus sebagai ruang abstrak/teoretis. Ruang yang dimaksud menghadirkan aktivitas dalam berkarya dan berpameran. Menurut Sucitra, terdapat beberapa ruang seni yang ada di Indonesia yaitu; (museum nasional dan milik pribadi), galeri (milik negara dan milik pribadi/swasta); kemudian terbagi lagi menjadi komersial dan nonprofit, dan ruang pamer juga bisa disebut galeri private dengan istilah (vanity gallert, artist-run space, artist initiative, artspace, alternative artspace, contemporary artspace). Galeri pribadi lebih cenderung pengelola galerinya ialah seniman atau komunitas seni, Anusapati (2003). Terdapat 4 jenis galeri berdasarkan status kepemilikan, antara lain: (1) Galeri seni milik lembaga pemerintah adalah pemerintah kota yang memiliki gedung atau ruangan untuk kegiatan pameran seni rupa; (2) Galeri seni milik perusahaan ialah perusahaan yang memiliki gedung atau ruangan yang digunakan untuk kegiatan pameran seni rupa; (3) Galeri seni milik individu ialah gedung atau ruangan yang difungsikan untuk kegiatan pameran seni rupa, galeri tersebut ada yang berbadan hukum dan tidak berbadan hukum, namun keduanya sama-sama milik individu; (4) Galeri dalam museum adalah museum yang memiliki ruangan khusus untuk penyelenggaraan kegiatan pameran seni rupa.

Manajemen galeri sangat berperan penting dalam menunjang keberlangsungan dalam mengatur kegiatan pameran didalamnya. Sebagai contoh: Rumah Seni Cemeti (Cemeti Art House) yang didirikan oleh seniman (Nindityo Adipurnomo dan Mella Jaarsma) pada tahun 1988, sampai saat ini lebih dari seperempat abad menjadi fasilitator bagi seniman-seniman kontemporer yang ada di Yogyakarta. Tahun 1995 didirikan sebuah Yayasan Seni Cemeti untuk mengelola dalam pengarsipan kegiatan yang berlangsung. Membaca perjalanan yang didapati oleh Rumah Seni Cemeti bisa menjadi contoh dalam bidang manajemen galeri dengan menjalankan berbagai program kegiatan pameran, diskusi, residensi, bahkan penulisan, dan 
saat ini Yayasan Seni Cemeti berganti nama menjadi IVAA (Indonesian Visual Art Archive). Rumah Seni Cemeti dan IVAA mempunyai visi dan anggaran masing-masing, bekerja dan menjadi dua organisasi yang terpisah. Di samping itu peran pemilik galeri juga sangat menentukan bagi keberlangsungan organisasi didalamnya dengan melakukan banyak perubahan dan pengembangan program kegiatan, sehingga bisa terus eksis dalam memamerkan karya seniman lokal dan mancanegara.

Dalam bahasan ini peneliti akan memfokuskan pada tiga galeri seni swasta yang pemiliknya seniman, seniman yang masih aktif berkarya dan eksis dalam berpameran. 1) Ugo Untoro sebagai pemilik galeri Museum dan Tanah Liat, 2) Lenny Ratnasari Weichert sebagai pemilik galeri Kersan Art Studio, dan 3) Putu Sutawijaya pemilik galeri Sangkring Art Space. Seniman yang eksis, cenderung memiliki karakteristik sendiri dalam kekaryaannya dan itu terbentuk untuk membedakan dirinya dengan seniman lainnya. Karakteristik yang dimaksud ialah hal membedakan individu satu dengan individu lainnya. Secara tidak langsung, karakteristik ini akan diterapkan ketika seorang seniman mendirikan sebuah galeri atau ruang seni.

Ugo Untoro, Lenny Ratnasari Weichert, dan Putu Sutawijaya dalam mendirikan sebuah galeri tentunya memiliki tujuan yang ingin dicapai, namun hal tersebut tidak tertulis secara terbuka (eksplisit). Dengan adanya manajemen (pengelola), galeri sebagai sumber daya manusia yang akan mengelola dan memaparkan tujuan tersebut menjadi sebuah visi-misi sesuai dengan kriteria atau karakteristik pemilik galeri. Menurut Mikke (2004: 27) pengertian manajemen dalam pengelolaan pameran seni rupa ialah suatu cara dalam memanfaatkan input untuk menghasilkan karya seni melalui suatu proses perencanaan, pengorganisasian, pengarahan, dan pengendalian dengan memperhatikan situasi dan lingkungan. Sedangkan menurut Charles dan Steven, (2008: 5) ada beberapa fungsi manajemen atau pengelolaan pada umumnya yaitu: Perencanaan dan Penyusunan Strategi (Planning and Strategy); Pengorganisasian (Organizing); Pengendalian (Controlling); Memimpin dan Mengembangkan (Leading and Development). Pernyataan para ahli tersebut menjelaskan tentang manajemen dalam pameran seni rupa dan manajemen pada umumnya, dalam setiap galeri juga akan menerapkan fungsi-fungsi manajemen tersebut, dan jelas dalam setiap galeri memiliki perbedaan dalam setiap pengelolaannya. Hal itu akan berkaitan dengan peran pemilik galeri pada sebuah manajemen galeri dalam memaparkan visi-misi yang sesuai dengan kriterianya.

"Museum dan Tanah Liat", "Kersan Art Studio", "Sangkring Art Space", memiliki perbedaan dalam kegiatan yang diselenggarakan oleh masing-masing galeri/art space: 1) Museum dan Tanah Liat merupakan galeri yang tidak berbadan hukum, semua kegiatan yang dilakukan merupakan dana sendiri berdasarkan hasil penjualan karya. Museum dan Tanah Liat lebih memfokuskan pada penyelenggaraan pameran tunggal, hal ini juga akan menjadi ciri khas pada Museum dan Tanah Liat, dan karya-karya yang ditampilkan secara tidak langsung sesuai dengan kriteria pemilik galeri (Ugo Untoro). 2) Kersan Art Studio merupakan galeri yang sudah memiliki badan hukum, dan memiliki dukungan dana dari perusahaan dalam menyelenggarakan kegiatan pameran. Kersan Art Studio lebih fokus pada kegiatan residensi seniman antarnegara. Lenny sebagai pemilik galeri lebih memanfaatkan jaringan internasional. 3) Sangkring Art Space merupakan galeri yang tidak berbadan hukum, kegiatan pameran yang diselenggarakan lebih mencakup pada semua ragam karya seni. Manajemen Sangkring Art Space secara umum memiliki tujuan untuk mewadahi seluruh seniman, khususnya seniman 
muda dan seniman yang profesional. Tiga galeri ini sangat berkompeten dan ikut andil dalam perkembangan seni rupa Yogyakarta, dan melihat akan peran pemilik galeri yang sama-sama seniman, dengan karakteristik manajemen yang tentunya beragam setiap galeri. Seniman dalam mendirikan sebuah galeri tentunya membutuhkan manajemen, dan sebuah manajemen galeri, akan membutuhkan sebuah ide-ide baru yang dimiliki oleh seniman. Ini yang menjadi menarik untuk diteliti jika dilihat dari kacamata manajemen mengenai peran seniman yang sebagai pemilik galeri. Secara tidak langsung, manajemen galeri bergantung pada peran pemilik galeri, karena pada umumnya pemilik galeri ikut andil dalam menentukan karya seni yang akan dipamerkan didalamnya. Pemilihan tiga objek galeri yang diteliti, dilihat dari kacamata manajemen dan ketiganya juga mewakili galeri seni swasta lainnya yang dimiliki oleh seniman di Yogyakarta.

\section{Metode Penelitian}

Metode penelitian kualitatif dengan menggunakan beberapa data antara lain:

1. Data Primer

\section{a) Observasi}

Observasi dilakukan dengan pengamatan perilaku dan aktivitas individu-individu di lokasi penelitian. Dalam pengamatan ini peneliti merekam/mencatat, baik dengan cara terstruktur maupun semi terstruktur. Peneliti mengamati proses kegiatan yang diselenggarakan di setiap galeri.

b) Wawancara

Wawancara dilakukan dengan subjek penelitian yang sudah ditentukan pada 3 pemilik galeri dan manajer/direktur galeri. Wawancara seperti ini menggunakan pertanyaan wawancara semi terstruktur yang dirancang untuk memunculkan pandangan dan opini para partisipan.

\section{Data Sekunder}

Selama proses penelitian, peneliti juga mengumpulkan data melalui studi dokumendokumen berupa dokumen katalog dan poster sebagai media promosi galeri atau media sosial yang digunakan oleh masing-masing galeri (website, Facebook).

\begin{tabular}{l} 
Variabel \\
$\qquad$\begin{tabular}{|l|l|l|}
\hline No. & Analisis isi & Variabel \\
\hline 1. & Kriteria karya seni dalam galeri & $\begin{array}{l}\text { Bahan } \\
\text { Media } \\
\text { Wujud } \\
\text { Isi }\end{array}$ \\
\hline 2. & Pengelolaan (management) & $\begin{array}{l}\text { Planning and strategy } \\
\text { Organizing } \\
\text { Controlling } \\
\end{array}$ \\
& & $\begin{array}{l}\text { Leading and Development } \\
\end{array}$
\end{tabular} \\
\hline
\end{tabular}

Tabel 4. Analisis isi dan Variabel

(Sumber: Wijayanto, 2017) 


\section{Hasil dan Pembahasan}

\section{Perbandingan}

Dalam perbandingan ini akan mencari perbedaan dan persamaan dari masing masing galeri.

1. Museum dan Tanah Liat

a) Perencanaan dan strategi (planning and strategy)

- Perencanaan (Planning)

Pemilik dan Manajemen membuat suatu perencanaan program kegiatan pameran setiap tahunnya, dan perencanaan tersebut biasanya masuk sebagai agenda proyek pameran. Museum dan Tanah Liat memiliki program proyek pameran yang biasanya diselenggarakan setiap tiga atau empat bulan sekali. Perencanaan kegiatan pameran biasanya dilakukan dalam setahun sekali, dengan rentan waktu enam bulan atau 1 tahun sebelum acara itu berlangsung. Perencanaan yang dilakukan dengan membagi tugas masing-masing tim berdasarkan strruktur organisasi dan waktu yang telah ditentukan dalam perencanaan tersebut.

- Strategi (Strategy)

Menggunakan jaringan kesenian yang dimiliki oleh pemilik galeri dan general manajer, seperti pertemanan. Tidak jarang jika seniman yang berpameran dalam Museum dan Tanah Liat yang lebih diutamakan ialah teman, namun ide dan konsepnya menarik dan sesuai dengan kriteria pemilik galeri. Memiliki kriteria karya seni yang akan dipamerkan dan menjadi salah satu galeri yang membedakan dengan galeri lain. Pemilik galeri cenderung memamerkan karya seniman yang menurutnya aneh, berbeda dengan yang lainnya dan memiliki konsep yang baru.

Pemilik galeri dan general manajer memikirkan ide-ide baru untuk program kegiatan berikutnya. General manager memiliki upaya dalam mempertahankan Museum dan Tanah Liat secara terus-menerus agar galeri tetap memiliki pemasukan untuk keperluan programprogram ke depannya. Hal itu dilakukan dengan cara menjual karya yang dipamerkan, dan tidak semena-mena untuk mencari-cari penghasilan. Karena ada beberapa kegiatan besar seperti Dolanan\#2 di Jogja Nasional Museum yang dilakukan oleh Museum dan Tanah Liat, dimana manajemen membuat sebuat perjanjian (MOU) dengan seniman yang mengikuti pameran, bahwa karya seni yang dipamerkan tidak dijual.

b) Pengorganisasian (Organizing):

Pengorganisasian dalam Museum Dan Tanah Liat ialah membagi tugas masing-masing tim berdasarkan keahlian masing-masing individu. General manager membagi tugas pada masing-masing tim yang telah ditentukan dalam struktur organisasi pada setiap penyelenggaraan pameran dan tidak pernah melakukan sebuah perubahan, hal itu dikarenakan general manager sudah mempercayai masing-masing individu berdasarkan kinerja pada kegiatan sebelumnya.

c) Pengendalian (Controlling):

Pemilik galeri berperan aktif dalam mengontrol tim kegiatan pameran, berdasarkan hasil, bahwa pemilik galeri mengawasi bagian-bagian yang berhubungan dengan visual, seperti tim publikasi (pembuatan poster, undangan, banner, dan katalog), tim display karya (mengontrol tampilan karya seni yang akan dipajang). 
Sedangkan general manager lebih kepada semua tim yang ada di bawahnya, mengontrol semua tim yang telah ditentukan dalam kegiatan pameran, dan general manager akan menerima laporan secara langsung dari Manajer proyek dan menerima laporan secara langsung dari manajer proyek mengenai perkembangan dan kebutuhan yang diperlukan, karena manajer proyek kinerjanya lebih kepada mengatur dan memantau semua tim.

d) Memimpin dan Mengembangkan Karyawan (Leading and Development):

Pemilik galeri dan general manajer memberikan secara tidaklangsung memberikan pengetahuan mengenai seni rupa kepada proyek manajer dan tim lainnya.

\section{Kersan Art Studio}

a) Perencanaan dan strategi (planning and strategy):

- Perencanaan (Planning)

Setiap tahunnya, pemilik galeri dan manajemen membuat suatu perencanaan program kegiatan pameran. Mendiskusikan kegiatan yang telah berlangsun pada tahun sebulumnya dan melakukan sebuah evalusi menganai kegiatan yang sudah terlaksana. Kemudian merencanakan kegiatan baru dangan ide, dan konsep baru pada kegiatan pameran, proyek pameran dan residensi.

Perencanaan dalam sebuah kegiatan, manajemen Kersan Art Studio membagi membagi tugas masing-masing tim sesuai waktu yang telah ditentetukan, dimulai dari rapat acara sampai dengan kegiatan berakhir.

- Strategi (Strategy)

Memiliki badan hukum, pembentukan Yayasan Kersan Art Studio mempermudah dalam pencarian dana dukungan atau sponsor, dan saat ini Yayasan Kersan Art Studio didukung oleh lembaga Asean Leadership Center. Pemilik galeri menggunakan jaringan kesenimanannya dengan memperluas dukungan dalam kegiatan yang diselenggarakan oleh Kersan Art Studio, seperti kegiatan residensi dan pameran proyek, tidak lain karena memiliki jaringan yang sangat luas. Mengembangkan program, dimana awal dari program Kersan Art Studio lebih mengutamakan pada pameran seniman perempuan, namun saat ini programnya dibuka untuk siapapun bagi seniman yang ingin berpameran, atas dasar ide dan konsep menarik dan sesuai dengan kriteria Kersan Art Studio, namun yang lebih diutamakan ialah konsep dan proses seniman dalam berkarya.

b) Pengorganisasian (Organizing):

Pemilik galeri sepenuhnya menyerahkan kepada Direktur dalam mengelola dan membagi tugas bersama Manajer Operasional. Manajemen yang secara intens mengelola terdapat dua orang, jadi semua kegiatan yang dibutuhkan, diatur oleh direktur dan manajemen.

c) Pengendalian (Controlling):

Pemilik galeri menerima laporan dari direktur dalam kegiatan pameran yang diselenggarakan, hal ini dikarenakan pemilik galeri berdomisili di Jakarta. Dengan begitu, direktur bertugas penuh dalam pengelolaan baik dalam publikasi (pembuatan poster, undangan, banner, dan katalog), dibantu dengan manajer operasional, sedangkan tim display tidak masuk dalam operasional, hanya saja apabila ada kebutuhan, manajemen akan meminta bantuan kepada asisten pemilik galeri atau luar yang profesional dalam menangani display karya dalam pameran.

d) Memimpin dan Mengembangkan Karyawan (Leading and Development): 
Pemilik galeri tidak semena-mena melepaskan direktur untuk mengelola, hal itu membutuhkan proses sangat panjang, dalam perjalanannya saat mengelola sebuah kegiatan, pemilik galeri secara tidak langsung memberikan pengetahuan mengenai seni rupa, dan bagaimana berkomunikasi yang baik dengan orang lain. Hal itu dilakukan oleh secara terus menerus oleh pemilik galeri sebelum ditugaskan untuk mengelola secara keseluruhan dalam Kersan Art Studio. Hal itu juga dilakukan oleh direktur kepada manajer operasional yang tidak memiliki latar belakang seni rupa. Jadi saat ini, manajer operasional tetap dibimbing dengan didampingi dalam mengelola Kersan Art Studio.

\section{Sangkring Art Space}

a) Perencanaan dan strategi (planning and strategy):

- Perencanaan (Planning):

Perencanaan kegiatan pameran dilakukan dalam setiap tahunnya oleh manajemen Sangkring Art Space membuat suatu perencanaan program kegiatan pameran setiap tahunnya, mengenai program proyek pameran dan pameran. Menerima saran dan masukan dari pemilik galeri mengenai konsep dan ide baru dalam sebuah kegiatan pameran. Melakukan sebuah evaluasi kegiatan pameran yang telah berlangsung, meminta pendapat dari seniman yang sudah berpameran mengenai kekurangan dari yang dimiliki oleh Sangkring Art Space, hal itu dilakukan agar manajemen bisa memperbaiki kekurangan dari fasilitas yang ada di dalam ruang pamer. Perencanaan yang dilakukan dalam Sangkring Art Space tidak merubah struktur organisasi yang sudah ada. Hal ini dilakukan karena berdasarkan pengalaman bertahun-tahun yang sudah dilakukan berulang kali, seperti misalnya tim display dan tim publikasi, dll. Hanya saja dari masing-masing tim menyesuaikan pada batas waktu yang telah direncanakan dalam sebuah kegiatan pameran.

- Strategi (Strategy):

Sangkring Art Space memiliki tiga ruangan yang memiliki berbeda konsep dalam penggunaannya, Sangkring Art Space, Sangkring Art Project, Balai Banjar. Dari ketiga ruangan ini konsepnya memiliki sejarah dan kegunaan tersendiri.

1) Sangkring Art Sapace digunakan untuk pameran semi-permanen yang berlangsung selama enam bulan sekali, pameran tersebut berlangsung sampai dengan enam bulan.

2) Sangkring Art Project digunakan untuk kegiatan pameran yang memiliki konsep proyek, dan biasanya pameran diselenggarakan dalam kurun waktu tiga bulan sekali.

3) Balai Banjar, ruang ini biasanya dipergunakan oleh seniman yang mengajukan pameran, dan ada satu dinding khusus yang spesial, dan dinding tersebut hanya diperuntukkan senimanseniman pilihan.

Pemilik galeri dan manajemen menggunakan jaringan kesenimanannya. Pemilik galeri lebih mengutamakan sistem pertemanan bagi seniman yang ingin berpameran, tentunya pemilik galeri mengerti siapa seniman yang akan dipamerkan tersebut, dan mengerti akan profesionalitas seniman yang akan berpameran. Meskipun demikian, keputusan akhir ada di tangan manajemen Sangkring Art Space.

Karya seni yang ditampilkan dalam Sangkring Art Space memiliki ragam karakter, dengan kata lain semua kriteria karya seni bisa masuk dalam dengan melalui seleksi dari manajemen. Dimana manajemen akan mendiskusikan mengenai konsep yang ditawarkan ke publik. 
Adanya konsep-konsep kegiatan baru yang dimiliki oleh Sangkring Art Space, seperti misalnya; Pameran tunggal ber-enam. Pameran tunggal yang biasanya diselenggarakan secara tunggal dengan satu seniman, namun Sangkring Art Space berani untuk membuat program pameran tunggal ber-enam. Hal ini menandakan bahwa pemilik galeri dan manajemen beserta kurator memikirkan ide-ide baru untuk program kegiatannya.

Direktur yang memiliki jabatan paling tinggi dalam manajemen Sangkring Art Space berusaha memberikan yang terbaik bagi seniman dan manajemennya. Manajemen juga berusaha membantu seniman menjual karya seni yang dipamerkan.

Manajemen Sangkring Art Space juga menerapkan sistem sewa ruangan atau galeri. Meskipun manajemen memiliki konsep seperti itu, semua seniman yang akan menggunakan ruangan tetap melalui sistem seleksi dengan mengajukan proposal diperiksa oleh manajemen Sangkring Art Space.

b) Pengorganisasian (Organizing):

Pada penyelenggaraan kegiatan setiap bulannya baik itu pameran dan proyek pameran, struktur organisasi yang berlaku tetap tidak diganti. Hal ini dikarenakan semua tim sudah terbiasa dengan sistem seperti itu. Tim display dan publikasi tetap dari Manajemen Sangkring, terkecuali pembuatan katalog. Seniman diperbolehkan mencetak katalog sendiri, dengan kata lain Manajemen Sangkring Art Space hanya mencetak katalog melalui website (e-katalog).

c) Pengendalian (Controlling):

Kegiatan yang yang diselenggarakan selalu mendapat pantauan dari direktur dan pemilik galeri. Direktur dan pemilik galeri berperan aktif dalam mengontrol masing-masing tim dalam pembuatan poster, undangan, banner, katalog dan display karya. Dengan begitu, semua kegiatan akan tetap terkendali mulai dari awal kegiatan sampai dengan kegiatan pameran berakhir.

d) Memimpin dan Mengembangkan Karyawan (Leading and Development):

Semua tim yang berada di struktur organisasi, tidak semuanya memiliki latar belakang seni rupa, terkecuali tim display. Jadi secara tidak langsung, pemilik pemilik galeri memberikan sebuah pengalaman mengelola galeri berupa praktek secara langsung atau mengenai pengetahuan seni rupa terhadap manajemen galeri dan seluruh tim didalamnya.

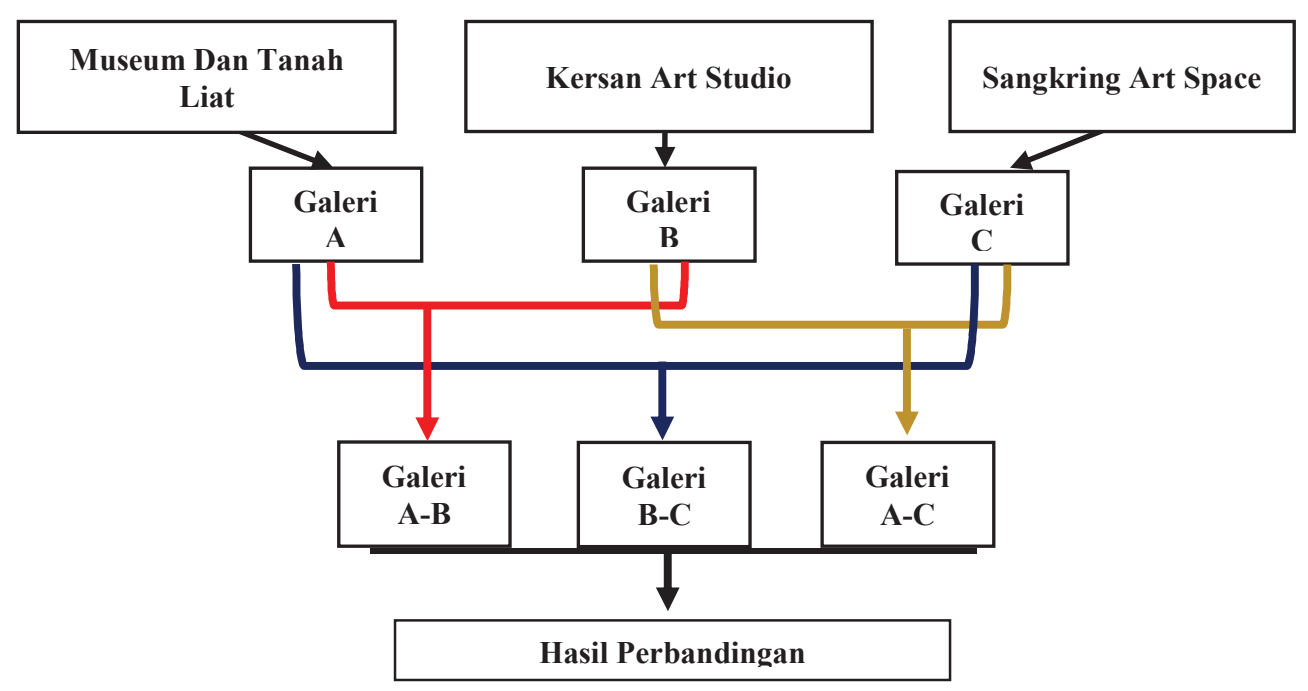

Bagan Skema 1. Pola Perbandingan Manajemen Galeri (Sumber: Wijayanto, 2017) 
Skema perbandingan yang dibuat untuk mencari perbedaan manajemen antara masingmasing galeri "Museum Dan Tanah Liat (MDTL) sebagai A", "Kersan Art Studio (KAS) sebagai B", Sangkring Art Space (SAS) sebagai C, perbedaan yang dihasilkan akan ditelaah dan dibahas mengenai perbedaan tersebut.

Tabel 1. Perbandingan Manajemen Galeri A-B

\begin{tabular}{|c|c|}
\hline \multicolumn{2}{|c|}{ PERBEDAAN } \\
\hline Galeri Museum Dan Tanah Liat (MDTL) & Kersan Art Studio (KAS) \\
\hline $\begin{array}{l}\text { Perencanaan dan Strategi } \\
\text { Perencanaan: } \\
\text { - Hanya pada proyek pameran. } \\
\text { - Tidak berbadan hukum. } \\
\text { - Tidak memiliki dukungan dana dari luar } \\
\text { (mandiri). } \\
\text { Strategi: } \\
\text { - Tidak pernah menerima submit proposal dari } \\
\text { seniman yang mengajukan pameran. } \\
\text { - Kriteria karya seni harus sesuai dengan } \\
\text { pemilik. } \\
\text { - General manager juga memikirkan mengenai } \\
\text { penjualan karya untuk keperluan program- } \\
\text { program ke depannya. } \\
\text { - Jarang melakukan evaluasi setelah kegiatan } \\
\text { pameran. }\end{array}$ & $\begin{array}{l}\text { Perencanaan dan Strategi } \\
\text { Perencanaan: } \\
\text { - KAS melakukan perencanaan program } \\
\text { pameran, proyek pameran dan residensi. } \\
\text { - Memiliki badan hukum. } \\
\text { - Memiliki dukungan dana. } \\
\text { Strategi: } \\
\text { - Menerima submit proposal seniman. } \\
\text { - Semua kriteria karya seni bisa masuk. } \\
\text { - Tidak mengutamakan penjualan karya. } \\
\text { - Melakukan evaluasi setelah kegiatan selesai } \\
\text { dengan seniman yang berpameran. }\end{array}$ \\
\hline $\begin{array}{l}\text { Pengorganisasian: } \\
\text { - Setiap kegiatan yang dilakukan menyesuaikan } \\
\text { dengan struktur dalam organisasi. }\end{array}$ & $\begin{array}{l}\text { Pengorganisasian: } \\
\text { - Minimnya tim pengelola dalam organisasi, } \\
\text { dua orang yang intens dalam mengelola } \\
\text { yaitu; Direktur dan Manajer Operasional. }\end{array}$ \\
\hline $\begin{array}{l}\text { Pengendalian: } \\
\text { - Pemilik galeri dan general manager sama- } \\
\text { sama mengontrol kinerja tim di lapangan }\end{array}$ & $\begin{array}{l}\text { Pengendalian: } \\
\text { - Tidak perlu dipantau, karena Direktur sudah } \\
\text { dipercaya bisa mengatasi kegiatan yang } \\
\text { diselenggarakan. }\end{array}$ \\
\hline $\begin{array}{l}\text { Memimpin dan Mengembangkan: } \\
\text { - Sama. }\end{array}$ & $\begin{array}{l}\text { Memimpin dan Mengembangkan: } \\
\text { - Sama. }\end{array}$ \\
\hline
\end{tabular}


Table 2. Perbandingan Manajemen Galeri A-C

\begin{tabular}{|c|c|}
\hline \multicolumn{2}{|c|}{ PERBEDAAN } \\
\hline Sangkring Art Space (SAS) & Kersan Art Studio (KAS) \\
\hline Perencanaan dan Strategi & Perencanaan dan Strategi \\
\hline $\begin{array}{l}\text { Perencanaan: } \\
\text { - Perencanaan program pameran, proyek } \\
\text { pameran, dan pameran. } \\
\text { - Tidak berbadan hukum. }\end{array}$ & $\begin{array}{l}\text { Perencanaan: } \\
\text { - Melakukan perencanaan program pameran, } \\
\text { proyek pameran, dan residensi. } \\
\text { - Berbadan hukum. }\end{array}$ \\
\hline $\begin{array}{l}\text { Strategi: } \\
\text { - Menerima submit proposal seniman. } \\
\text { - Semua kriteria karya seni bisa masuk dengan } \\
\text { melalui proses seleksi manajemen. } \\
\text { - Dana dari hasil penjualan karya untuk } \\
\text { keperluan program-program kedepannya. } \\
\text { - Memiliki tiga ruang pamer (Balai Banjar, } \\
\text { Sangkring Art Project, dan Sangkring Art } \\
\text { Space. }\end{array}$ & $\begin{array}{l}\text { Strategi: } \\
\text { - Menerima submit proposal seniman. } \\
\text { - Memiliki dukungan dana dan tidak } \\
\text { mengutamakan penjualan karya. } \\
\text { - Memiliki jaringan seniman asing untuk } \\
\text { bekerja sama dalam pameran atau residensi. } \\
\text { - Memiliki satu ruang pamer. }\end{array}$ \\
\hline $\begin{array}{l}\text { Pengorganisasian: } \\
\text { - Tim dalam organisasi yang sudah dibentuk } \\
\text { dengan dan masing-masing tim memiliki } \\
\text { tugas. }\end{array}$ & $\begin{array}{l}\text { Pengorganisasian: } \\
\text { - Minimnya tim pengelola dalam organisasi } \\
\text { yang berperan aktif yaitu (Direktur dan } \\
\text { Manajer operasional). }\end{array}$ \\
\hline $\begin{array}{l}\text { Pengendalian: } \\
\text { - Pemilik galeri dan Direktur sama-sama } \\
\text { mengontrol kinerja tim di lapangan, dalam } \\
\text { kantor dan saat display pameran. }\end{array}$ & $\begin{array}{l}\text { Pengendalian: } \\
\text { - Tidak perlu dipantau, karena Pemilik galeri } \\
\text { sudah mempercayai Direktur dan Manajer } \\
\text { Operasional dalam mengatasi kegiatan yang } \\
\text { diselenggarakan. }\end{array}$ \\
\hline $\begin{array}{l}\text { Memimpin dan Mengembangkan } \\
\text { - Sama. }\end{array}$ & $\begin{array}{l}\text { Memimpin dan Mengembangkan } \\
\text { - Sama. }\end{array}$ \\
\hline
\end{tabular}


Tabel 3. Perbandingan Manajemen Galeri C-B

\begin{tabular}{|c|c|}
\hline \multicolumn{2}{|c|}{ PERBEDAAN } \\
\hline Galeri Museum Dan Tanah Liat (MDTL) & Sangkring Art Space (SAS) \\
\hline Perencanaan dan Strategi & Perencanaan dan Strategi \\
\hline $\begin{array}{l}\text { Perencanaan: } \\
\text { - Hanya proyek pameran. }\end{array}$ & $\begin{array}{l}\text { Perencanaan: } \\
\text { - Membuat perencanaan program pameran, } \\
\text { dan proyek pameran. }\end{array}$ \\
\hline Strategi: & Strategi: \\
\hline $\begin{array}{l}\text { - Tidak pernah menerima proposal dari } \\
\text { seniman yang mengajukan pameran. } \\
\text { - Kriteria karya seni harus sesuai dengan } \\
\text { pemilik. } \\
\text { - Hanya seniman-seniman tertentu yang bisa } \\
\text { menyewa ruangan untuk pameran. } \\
\text { - Jarang melakukan evaluasi setelah kegiatan } \\
\text { pameran. }\end{array}$ & $\begin{array}{l}\text { - Menerima submit proposal seniman. } \\
\text { - Semua kriteria karya seni bisa masuk dengan } \\
\text { melalui proses seleksi manajemen. } \\
\text { - Menyewakan ruangan untuk kegiatan } \\
\text { pameran dengan melalui proses seleksi. } \\
\text { - Melakukan evaluasi setelah kegiatan selesai } \\
\text { dengan seniman yang berpameran. } \\
\text { - Memiliki tiga ruang galeri }\end{array}$ \\
\hline $\begin{array}{l}\text { Pengorganisasian: } \\
\text { - Sama }\end{array}$ & $\begin{array}{l}\text { Pengorganisasian: } \\
\text { - Sama }\end{array}$ \\
\hline $\begin{array}{l}\text { Pengendalian: } \\
\text { - Sama }\end{array}$ & $\begin{array}{l}\text { Pengendalian: } \\
\text { - Sama }\end{array}$ \\
\hline $\begin{array}{l}\text { Memimpin dan Mengembangkan } \\
\text { - Sama }\end{array}$ & $\begin{array}{l}\text { Memimpin dan Mengembangkan } \\
\text { - Sama }\end{array}$ \\
\hline
\end{tabular}

\section{Hasil Perbandingan}

Pemilik dari masing-masing galeri memiliki peran yang berbeda dalam manajemen, dengan memberikan saran dalam program kegiatan pameran yang akan direncanakan setiap tahunnya. Pemilik galeri dari ketiga objek penelitian memiliki kriteria tersendiri dalam merekomendasikan karya seniman yang akan dipamerkan di galeri kepada manajemen. Pameran yang diselenggarakan yang paling diutamakan ialah jaringan atau jalinan pertemanan sesama seniman. Manajemen dan pemilik galeri menilai bahwa pertemanan tersebut akan menyangkut profesionalitas dan kedekatan dalam profesi yang sudah memiliki tanggung jawab dalam berkesenian maupun target yang akan dicapai.

Ketiga galeri setiap tahunnya sama-sama memiliki program mengenai kegiatan pameran, proyek pameran ataupun diskusi seni rupa. Program yang dilakukan oleh Museum Dan Tanah Liat (MDTL) berfokus pada proyek pameran, dan diskusi seni rupa. Kersan Art Studio (KAS) semua program kegiatan yaitu pameran, proyek pameran, dan residensi. Sedangkan Sangkring Art Space (SAS) program kegiatan yang direncanakan lebih lengkap, berhubung memiliki ruang yang cukup untuk kapasitas pameran yang lebih besar, program kegiatannya berupa proyek pameran dan pameran.

Kelebihan dari Kersan Art Studio (KAS) ialah memiliki dukungan dana dari perusahaan, sedangkan galeri yang belum berbadan hukum seperti Museum Dan Tanah Liat (MDTL) dan Sangkring Art Space (SAS) akan membutuhkan dana anggaran agar bisa menjalankan program berikutnya. Museum Dan Tanah Liat dan Sangkring Art Space di tahun 2015 mulai mengurus pembentukkan suatu yayasan untuk mendukung sebuah kegiatan atau pameran yang berkapasitas besar, atau hal itu juga untuk mempermudah dalam pencarian dana dukungan. 
Rata-rata dari masing-masing galeri memikirkan anggaran pendanaan untuk meneruskan program kegiatan yang berkelanjutan dengan cara menjual karya dan menyewakan galeri (sistem sewa). Pengelola di masing-masing galeri tidak memiliki latar bekang pendidikan manajamen, meskipun demikian hasil dari penelitian ini, semua pengelola galeri menerapkan fungsi-fungsi manajemen secara umum, mengenai perencanaan, strategi, pengorganisasian, pengendalian, memimpin, dan pengembangan karyawan. Hal itu diterapkan karena dari sekian lama mereka mengelola dan terus membenahi manajemen dari pengalaman yang pernah terjadi sebelumnya. Setiap galeri menunjukkan relasi atau hubungan manajemen dengan seniman yang akan berpameran atau yang sudah pameran terus terjaga, karena manajemen menyadari akan keberlanjutan kegiatan yang akan diselenggarakan, dan itu saling berhubungan terusmenerus.

\section{Kesimpulan}

Seniman sebagai pemilik galeri memiliki peran penting terhadap manajemen dengan memberikan ide-ide dan konsep kegiatan pameran yang kemudian diproses oleh manajemen galeri. Secara tidak langsung, awal dan proses pembentukan dalam galeri yang memiliki visimisi galeri ialah pemilik, kemudian manajemen menerapkan hal tersebut menjadi bentuk yang nyata dalam kegiatan pameran. Pemilik galeri memiliki peran yang berbeda-beda di setiap galeri, seperti misalnya "Museum Dan Tanah Liat", "Kersan Art Studio", "Sangkring Art Space". Masing-masing galeri dalam pemilihan karya seni sesuai dengan kriteria pemilik galeri yang menjadi ciri khas dari galeri tersebut.

Pemilik galeri dan Kurator penting adanya, sebagaimana kurator akan menerjemahkan kriteria karya seni yang sesuai kriteria pemilik galeri, dan kurator akan menjabarkan bahasa seni rupa yang dimiliki oleh seniman, dengan begitu kurator akan menaikkan eksistensi perupa. Seniman juga bisa menyampaikan secara lisan, namun secara tulisan sangat jarang sekali. Maka dari itu, kurator memiliki tugas untuk menafsirkan karya seni menjadi sebuah tulisan agar lebih mudah dipahami oleh publik. Sehingga sangat penting akan keberadaan kurator tersebut.

Manajemen akan meminta pertimbangan terhadap karya-karya yang akan dipamerkan didalamnya. Kurator akan melihat isi, ide, dan konsep yang ditawarkan seniman kepada manajemen. Dalam hal ini, manajemen dan kurator akan mempertimbangkan karya seni yang terkait dengan kebutuhan ruang, pembuatan katalog, dan kebutuhan publikasi.

Manajemen yang ada di "Museum Dan Tanah Liat", "Kersan Art Studio", dan "Sangkring Art Space" terdapat perbedaan yang menjadi ciri khas tersendiri mengenai program kegiatan pameran yang diselenggarakan. Secara tidak langsung memiliki tujuan yang memfasilitasi seniman dalam mempermudah mendapatkan infrastruktur untuk mempublikasikan ataupun mempromosikan karya seni yang diciptakan. Manajemen menyadari akan pentingnya jaringan dibantu dengan jaringan kesenian yang dimiliki oleh pemilik galeri.

\section{Saran}

Manajemen di masing-masing galeri memiliki pelaksanaan, konsep, dan tujuan yang berbeda. Selama ini yang perlu dipikirkan ialah mempertahankan eksistensi kegiatan pameran 
yang harus terus berlanjut. Berdasarkan hasil penelitian, terdapat beberapa hal yang membedakan dari tiap galeri, di antaranya:

- Museum Dan Tanah Liat (MDTL)

Anggaran dana yang dikeluarkan oleh Museum Dan Tanah Liat masih menggunakan dana pribadi dan menggunakan hasil penjualan karya untuk program berkelanjutan. Selama ini Museum Dan Tanah Liat masih belum merencanakan untuk mencari dana dari sponsor dalam setiap kegiatannya. Disarankan untuk MDTL agar ada tim pengelola galeri setiap harinya, dengan seperti itu akan ada yang merancang program kegiatan yang terus berkelanjutan, seperti pencarian dana pendukung untuk pameran, merencanakan program kegiatan baru, karena selama ini Museum Dan Tanah Liat masih berfokus pada proyek pameran. Menerima submit proposal bagi seniman yang ingin berpameran di Museum Dan tanah Liat. Museum Dan Tanah Liat sebaiknya memanfaatkan properti yang dimiliki dengan menyewakannya sebagai alternatif ruang berpameran bagi penggiat seni di Yogyakarta. Tentunya dengan menyewakan ruang galeri, juga berdasarkan pada karya seni yang sesuai dengan kriteria pemiliki galeri, dengan kata lain harus melalui tahap seleksi manajemen.

- Kersan Art Studio (KAS)

Program-program kegiatan yang dimiliki oleh Kersan Art Studio selalu berjalan dengan lancar. Melihat dari hasil penelitian, dengan adanya dua pengelola galeri yang aktif, disarankan untuk Kersan Art Studio menambah sumber daya pengelola, agar program-program yang berskala besar lebih mudah dijalankan dengan adanya tenaga tambahan.

Promosi yang dilakukan oleh Kersan Art Studio memungkinkan untuk menambah kapasitas melalui undangan secara resmi, karena dalam lingkup seni rupa bentuk secara fisik undangan akan lebih memungkinkan seniman lain untuk datang ke pameran. Mengenai kurator tetap Kersan Art Studio, disarankan untuk tetap mengkurasi kegiatan-kegiatan kecil seperti penyelenggaraan pameran tunggal. Hal itu juga akan menambah wawasan dan penggalian lebih dalam terhadap seniman yang berpameran. Jumlah karya seni yang dipamerkan juga menentukan kapasitas ruang yang ada di ruang pameran Kersan Art Studio sangat terbatas. Lebih memungkinkan bagi Kersan Art Studio ketika menyelenggarakan pameran yang berskala besar untuk bekerja sama dengan galeri lain, karena terbatasnya ruang pamer yang ada di Kersan Art Studio. Alternatif lain untuk program kegiatan bisa lebih diperbanyak pada pameran tunggal, jika melihat kondisi keterbatasan ruang. Konsep studio yang dimiliki oleh Kersan Art Studio, ada baiknya lebih diperkuat dalam dokumentasi secara audio visual, karena dalam hal ini akan merekam semua proses kerja seniman atau kegiatan yang dilakukan oleh seniman selama berada di Kersan Art Studio.

- Sangkring Art Space (SAS)

Hasil penelitian yang dilakukan di Sangkring Art Space (SAS), menunjukkan bahwa manajemen Sangkring Art Space dikelola secara baik. Terbukti pada setiap bulannya selalu ada kegiatan yang diselenggarakan secara intens. Tersedianya sumber daya manusia yang mengelola manajemen setiap harinya memungkinkan Sangkring Art Space menyelenggarakan kegiatan pameran yang berskala besar. Ruang pamer yang berjumlah tiga, yaitu: 1) Sangkring Art Space digunakan untuk pameran semi permanen yang berlangsung selama enam bulan sekali setiap tahunnya; 2) Balai Banjar digunakan untuk kegiatan pameran setiap bulannya; 3) Sangkring Art Project digunakan untuk kegiatan yang berkonsep proyek pameran. Sangkring 
Art Space juga menerima pengajuan proposal dari seniman yang memiliki ketertarikan untuk berpameran. Program-program kegiatan yang seperti diharapkan tetap dipertahankan, hanya saja butuh ide-ide baru untuk program yang berkelanjutan. Disarankan pula bagi Sangkring Art Space untuk mencari dan bekerja sama dengan lembaga lain, seperti misalnya pencarian sponsor bagi kegiatan pameran yang berkapasitas besar maupun kecil.

\section{Implikasi Manajerial}

Penelitian ini hanya sebatas membahas tentang peran seniman yang memiliki galeri dan juga membahas mengenai perbedaan manajemen di masing-masing galeri: Museum Dan Tanah Liat (MDTL), Kersan Art Studio (KAS), dan Sangkring Art Space (SAS). Hasil yang didapatkan dari penelitian terhadap masing-masing galeri menunjukkan keberagaman karakter manajemen dari setiap galeri. Penelitian ini memiliki kelemahan dalam penggalian data mengenai ciri khas karya seni dari masing-masing galeri. Diharapkan untuk penelitian selanjutnya membahas tentang ciri khas karya seni. Serta diharapkan pula penelitian selanjutnya membahas lebih dalam tentang karakteristik seniman dalam manajemen ditinjau dari kacamata psikologi. Di sisi lain pembahasan mengenai sumber daya manusia dalam manajemen organisasi galeri juga belum tersentuh secara maksimal. Saran bagi penelitian selanjutnya yaitu membahas tentang karakteristik manajemen galeri swasta, bisa melengkapi penelitian tersebut seperti yang telah dipaparkan di atas.

\section{Kepustakaan}

Aldrich, Virgil C. 1963. Philosophy of Art. Prentice-Hall, Englewood Cliffs, NJ.

Anusapati. 2003. Katalog 15 Years Cemeti Art Home Exploring Vacuum, Yogyakarta: Rumah Seni Cemeti.

Arikunto, Suharsimi. 2010. Prosedur penelitian: Suatu Pendekatan Praktek (revisi). Jakarta: PT. Rineka Cipta.

Arcodia, C. 2004. New directions for art galleries and museums: the use of special events to attract audiences-a case study of the Asia Pacific Triennial. Las Vegas International Hospitality and Convention Summit (pp. 1-19). University of Las Vegas.

Arya, Sucitra, I Gede. 2015. Ketika Seniman Membangun Galeri: Kajian Manajemen Strategik Ruang Sangkring Art Space Yogyakarta. Yogyakarta: FSR ISI Yogyakarta.

Cresswell, John. 2013. Penelitian kualitatif \& Desain Riset: Memilih diantara Lima Pendekatan Yogyakarta: Pustaka Pelajar. 2016. Research Design: Pendekatan Metode Kualitatif, Kuantitatif dan Campuran. Yogyakarta: Pustaka Pelajar.

Drive, SW, Jefferson. 2002. The Making of Exhibitions: Purpose, Structure, Roles And Process. Smithsonian Institution, Office of Policy and Analysis, 1000 Washington DC 20560-0039.

Fernandes, A., \& Afonso, L. U. 2014. Joana Vasconcelos: Managing an Artist's Studio in the 21st Century. International Journal of Arts Management, 17(1), 54.

Indarto, Effy. Handayani, Tri Lestyo. 2014. Studi Manajemen Penyelenggaraan Pameran Seni Rupa di Bentara Budaya Yogyakarta. Brikolase, Vol. 6, No.1.

M. Harris. Cyril. 2006. Dictionary of Architecture and Contruction: Fourth edition. New York: McGraw-Hill Companies. 
Papanikolaou, Panagiota. 2013. Managing an Exhibition: The Example of the Municipal Art Gallery of Thessaloniki. American International Journal of Social Science, Vol. 2 No. 4.

Prajitno, Hari. 2016. Transformasi Pohon Sebagai Simbol Spiritual Religius Dalam Penciptaan Seni Rupa., Tesis Penciptaan Seni, PPPSISI Yogyakarta.

Putra, Y. H. 2012. Galeri Seni rupa di Yoyakarta (Doctoral dissertation, UAJY).

Rosin, R. 2016. Artistic research on two galleries in periphery.

Stepanskaya, T. M. 2016. Educational Activities at University Museums and art Galleries as the European Tradition. International Review of Management and Marketing, 6(3S).

Susanto, Mikke. 2004. Menimbang Ruang Menata Rupa-Wajah Tata Pameran Seni Rupa. Yogyakarta: Galang press.

Susanto, Mikke. 2011. Diksi Rupa: Kumpulan istilah dan gerakan seni rupa. Yogyakarta: Dictiart Lab \& Djagad Art House.

W.L. Hill. Charles and L. Mc Shane. Steven. 2008. Principle of Manajement. Amerika, New York: McGraw-Hill/Irwin, Inc 1221.

\section{Sumber Internet}

http://sangkringart.com/profile-3/, Rabu, 3 Mei 2017, pukul 22:43 WIB. Website galeri sangkring.

http://www.artinya.id/2016/03/artinya

http://www.cemetiarthouse.com/ Selasa, 4 April 2017, pukul 13:06 WIB. Website galeri cemeti art house.

http://www.googlemaps.com/ Rabu, 5 April 2017, pukul 17:45 WIB. Peta lokasi Kasihan, Bantul, Yogyakarta.

http://www.kersanartstudio.com/ Selasa, 4 April 2017, pukul 14:44 WIB. Website galeri kersan art studio

http://www.museumdantanahliat.co/, Selasa 5 Mei 2017, pukul 18:09 WIB. Website galeri museum dan tanah liat. 